\title{
Systèmes d'Information et Management
}

2014

\section{Exploring the Long Shadow of IT Innovation Adoption Decisions on IT Value}

Yasser Rahrovani

Desautels Faculty of Management, McGill University, rahrovani@gmail.com

Shamel Addas

IESEG School of Management, Lille, France, s.addas@ieseg.fr

Alain Pinsonneault

Desautels Faculty of Management, McGill University, alain.pinsonneault@mcgill.ca

Follow this and additional works at: https://aisel.aisnet.org/sim

\section{Recommended Citation}

Rahrovani, Yasser; Addas, Shamel; and Pinsonneault, Alain (2014) "Exploring the Long Shadow of IT Innovation Adoption Decisions on IT Value," Systèmes d'Information et Management: Vol. 19 : Iss. 4 , Article 2.

Available at: https://aisel.aisnet.org/sim/vol19/iss4/2

This material is brought to you by the AIS Affiliated and Chapter Journals at AIS Electronic Library (AISeL). It has been accepted for inclusion in Systèmes d'Information et Management by an authorized administrator of AIS Electronic Library (AISeL). For more information, please contact elibrary@aisnet.org. 


\title{
Exploring the impact of organizational climate factors on organizational creativity within a centralized IS
}

\section{Anis KHEDHAOURIA, Nassim BELBALY \& Hind BENBYA}

\author{
Montpellier Business School/Montpellier Research in Management
}

\begin{abstract}
The present study aims to illustrate problems associated with enabling organizational creativity through a centralized information system (IS). A creativity model based on the componential creativity theory was adapted from organization theory and was used to develop propositions regarding organizational climate factors that should be avoided when using a centralized IS to foster organizational creativity. The present study offers a useful case study to help organizations understand actions to be avoided when seeking to enhance organizational creativity via the adoption of a centralized IS.
\end{abstract}

Keywords: Organizational creativity, Componential creativity theory, Centralized information systems, Organizational climate factors.

\section{RÉSUMÉ}

La présente étude vise à illustrer les problèmes associés au développement de la créativité organisationnelle via un système d'information (SI) centralisé. Un modèle basé sur la théorie de la créativité componentielle a été adapté et utilisé pour formuler des propositions concernant les facteurs du climat organisationnel négatifs sur la créativité organisationnelle via un SI centralisé. La présente étude offre un cas intéressant qui illustre un exemple d'actions à éviter.

Mots-clés : Créativité organisationnelle, Théorie componentielle de la créativité, Systèmes d'information centralisés, Climat organisationnel. 


\section{INTRODUCTION}

Organizational creativity is a critical phase in the innovation process and is considered as a source of competitive advantage (Amabile, 2013; Jameux and Khedhaouria, 2009). It is defined as the generation of a valuable and useful new idea about a product, service, or procedure by individuals working together in a social system (Woodman et al., 1993). Information systems (IS) can facilitate creative processes through information sharing and organizational learning (Benbya and Meissonier, 2007; Dewett, 2003). Previous studies argued that organizational creativity is greatly influenced by whether IS governance has a decentralized or centralized design (King, 1983; Sambamurthy and Zmud, 1999).

In the decentralized governance mode, individual business units assume the authority for all IS activities, such as IS infrastructure management, IS use management, and project management (Brown and Magill, 1994). The decentralized IS approach gives individual business units the autonomy over all of their own IS resources without any major considerations over other units, unless it is essential to the overall organization policy (Olson and Chervany, 1980). The IS literature considers the decentralized IS approach as a major promoter of organizational creativity due to the flexibility and responsiveness favored by the increased autonomy (Bansler et al., 2000; King, 1983). However, the lack of centralized control in decentralized IS can impede creative processes by increasing conflicting ideas, misunderstanding of problems, duplication of resources, ef- fort, expertise, and time (Von Simson, 1990).

With the centralized governance mode, corporate IS has the authority for all IS activities (Brown and Magill, 1994). The main characteristics of a centralized IS approach are organizational integration, control, efficiency, and economy (Bloomfield and Coombs, 1992). Although centralized IS is suggested to promote efficient and controlled organization, information access, resources sharing, avoidance of duplication, and organizational learning, the inflexibility of such systems can generate rigid practices that can limit the autonomy necessary for creative processes (Bloomfield and Coombs, 1992).

Adopting a centralized IS approach can bring efficiency benefits but requires an appropriate climate to promote organizational creativity (Cooper, 2000). Although a rich IS literature has increased our understanding of why firms choose a centralized IS (Bansler et al., 2000; Brown and Magill, 1994; Brown, 1997; Sambamurthy and Zmud, 1999), little attention has been given to explain what organizational climate factors should be avoided to enhance organizational creativity through the use of a centralized IS.

The present study provides a "failure story" that aims to illustrate the problems associated with using a centralized IS to enable organizational creativity. A creativity model based on the componential creativity theory (Amabile, 1988) was adapted from organization theory and used to develop propositions regarding the organizational climate factors that should be avoided to foster organizational creativity. Specifically, we 
used the model to understand how Schneider Electric failed to enable organizational creativity through its centralized IS called "Corporate Intranet."

Four main issues negatively impacted organizational creativity through intranet at Schneider Electric. The first involves creativity operationalization (i.e., the management was driven by economic results without considering creative processes), the second concerns the organization (i.e., intentions about intranet implementation were not clearly communicated to users), the third concerns IT management (i.e., users' needs and development requirements were missing), and the last concerns management practices (there was no management support to promote creative use).

The present study makes several contributions. First, it details the climate factors that should be avoided to enhance creative processes through IS. Second, it conceptualizes the perspective that a centralized IS can bring efficiency but requires an appropriate climate to enhance organizational creativity. Third, it uses the Schneider Electric case study to illustrate and challenge some of the findings of the literature review on the organizational creativity model. Last, Schneider Electric's case study may help managers to effectively understand actions that should be avoided to enable organizational creativity within a centralized IS.

\section{ORGANIZATIONAL CREATIVITY MODEL}

Due to its indisputable relevance to individuals, groups and organizations, the concept of creativity has been widely discussed over the past few decades in a variety of disciplines, including psychology, sociology, organizational behavior, and IS (Amabile, 1988; Cooper, 2000; Khedhaouria and Ribiere, 2013; Mumford and Gustafson, 1988; Woodman et al., 1993). While other disciplines have paid great attention to the subject, the IS discipline has tended to overlook many of the issues related to creativity (Seidel et al., 2010). Creativity research in IS has focused on methods, techniques and tools (Garfield et al., 2001), the requirements and strategies for disseminating them (Snow and Couger, 1991), and support systems for individuals and groups (Massetti, 1996). These research streams suggest a need to develop a comprehensive creativity model for the IS discipline (Seidel et al., 2010). Seidel et al. (2010) analyzed the main IS journals and found Rhodes' 4-P model to be the most frequently used creativity framework. The elements of the 4-P model are creative processes, creative persons, creative products, and creative press or situations. IS studies using the 4-P model have mainly focused on creative products and creative processes and have acknowledged the relevance of the interrelationships between the 4-Ps (Satzinger et al., 1999, Tiwana and McLean, 2005).

The 4-P model was adapted for two creativity models frequently referenced in the literature, the interactionist model (Woodman et al., 1993) and the componential model (Amabile, 1988) of organizational creativity. The interactionist model brings the perspective of interactional psychology to bear on 
the integration of process, product, person, and situation into a comprehensive theory of organizational creativity. In spite of its theoretical relevance, the interactionist model has not been empirically tested (Cooper, 2000). The componential model is not a multilevel model (Klein and Kozlowski, 2000) but provides a comprehensive model of the psychological and social components necessary for an individual to produce a creative work. It is recognized as one of the major models of creativity in organizations and it has been empirically tested in various settings (Amabile, 2013), which explains its relevance for our study. The componential model builds on the assumption that individual creativity can be fostered within an appropriate organizational context (Amabile, 1996). Organizational context is considered as a major condition that supports organizational creativity (Tushman and O'Reilly, 1996). Recent research on innovation suggests the need to further investigate the effect of organizational context on organizational creativity (Garud et al., 2013). Our research addresses these issues.

The componential model (see Figure 1), includes major conceptual categories and specifies the main components of each category and the predicted relationships between each factor and organizational creativity. Factors assumed to negatively affect organizational creativity are referred to as "obstacle factors." Within each category, the psychological mechanisms underlying the hypothesized effect on creative behaviors are briefly described.
To adapt this model to a centralized IS context, we added training as an effective resource because IS studies stressed its importance for IS use and learning (Bostrom et al., 1990; Davis and Davis, 1990). In a centralized IS context, training refers to enabling sufficient skills for effective interaction with the IS (Alavi and Joachimsthaler, 1992).

In the following section, we describe our research model and its suggested propositions.

\section{I.1. Creativity encouragement}

\section{I.1.1. Organizational encouragement}

Risk taking: Risk taking theory categorizes two decision maker behaviors (Sitkin and Pablo, 1992): risk-averse decision makers who prefer low risks and high certainty, and risk-seeking decision makers who prefer high risks and tolerate uncertainty. Attitudes toward risk are usually related to dimensions of personality such as motivation and creativity (Dewett, 2007). Creative outcomes usually result from risk-seeking behaviors (Amabile et al., 1996). In problem-solving activities, individuals who seek risks may often seek knowledge from various sources (e.g., published documents, knowledge-based systems, and community network sites), even those considered as unreliable (i.e., informal sources), to learn about the problem (Gray and Durcikova, 2005; Gray and Meister, 2006). In such activities, risk-seeking decision makers can turn a crisis into an opportunity by investing heavily in the acquisition of new tacit and explicit 


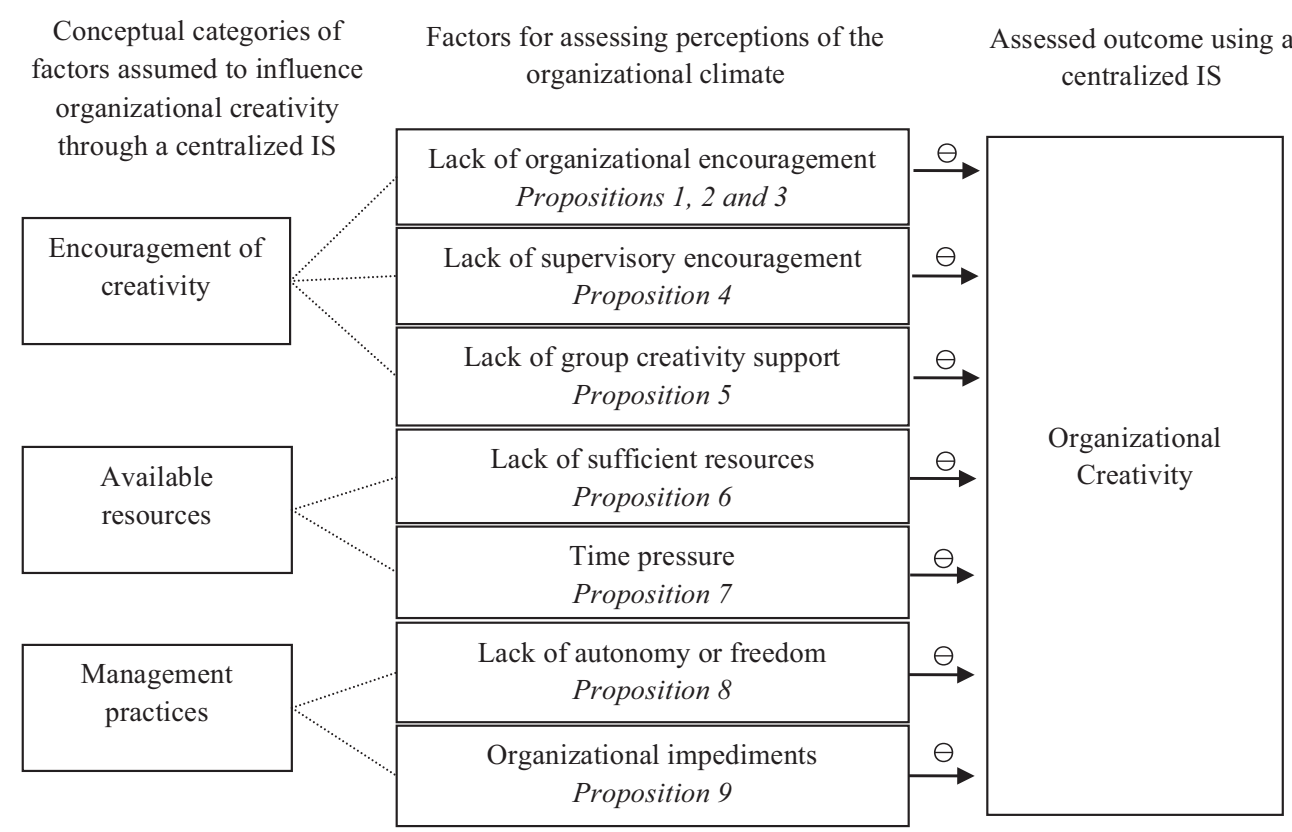

\section{Figure 1: Modified conceptual model of componential creativity (adapted from Amabile, 1988)}

knowledge to creatively overcome the critical situation (Kim, 1998). Riskseeking behaviors consistently tend to believe they can overcome risk through their self-determination (Krueger and Dickson, 1994).

IS studies suggested that encouraging risk taking behaviors can motivate users to be involved in IS adoption (Alavi and Joachimsthaler, 1992; Cooper, 2000). Risk-takers are more likely to develop positive intentions towards new IS use because they are more attracted by innovation and tolerate uncertainty (Agarwal and Prasad, 1998). An appropriate climate should provide adequate organizational incentives for allowing risk-taking behaviors. In addition, management should distinguish individuals who have been brilliant risk takers from those who have been foolish gamblers (March and Shapira, 1987). Prohibiting mistakes has been suggested to inhibit taking "good" risks and thereby to hamper creative processes when using an IS (Alavi and Joachimsthaler, 1992). This leads to the following proposition:

P1: The lack of risk taking will impede organizational creativity when using a centralized IS.

Task motivation: A number of theories seek to explain human motivation. The Self-efficacy theory (Deci and Ryan, 1985) distinguishes between intrinsic motivation, which "refers to doing something because it is inherently interesting or enjoyable," and extrinsic motivation, which "refers to doing something because it leads to a separable outcome" (Ryan and Deci, 2000 , p. 55). Research has used moti- 
vation theory to explore the factors that influence an IS acceptance and its creative use (Davis et al., 1992). Creative use is defined as the willingness of an individual to try out a new IS to develop new outcomes that enhance activity performance (Agarwal and Prasad, 1998). IS research has been concerned with extrinsic motivation and explores what instrumental outcomes outside the activity itself influence the performance of an activity (Davis, 1989). Drawing upon the theory of reasoned action (Ajzen and Fishbein, 1980), the technology acceptance model posits that individual intentions to creatively use the technology are driven by attitudes towards IS use. Attitudes, in turn, are premised to be determined by two salient beliefs about the IS: perceived usefulness, i.e., the individual's subjective assessment of the utility offered by the IS in a specific work-related context, and perceived ease of use, i.e., the cognitive effort that needs to be expended to utilize the IS. In the context of utilitarian IS, perceived usefulness is considered as central to the prediction of intentions to use an IS (Van der Heijden, 2004). Perceived usefulness is operationalized as an extrinsic motivation and suggested to be the main determinant of behavioral intentions to creatively use an IS (Agarwal and Prasad, 1998). The absence of extrinsic motivation has been found to impede creative processes when using an IS. For instance, Stenmark (2005) described the failure of an IS support for organizational creativity because users did not perceive any utility offered by such a system. This leads to the following proposition:
P2: The lack of extrinsic motivation to use a centralized IS will impede organizational creativity.

Other studies have focused on the role of intrinsic motivation, which involves performing an activity because it is inherently enjoyable or challenging (Hwang, 2005). Van der Heijden, (2004) found that perceived enjoyment - i.e., the extent to which the activity of using an IS is perceived to be enjoyable - and perceived ease of use are the main intrinsic motivational dimensions that determine the creative use of an IS. Similarly, Hackbarth et al. (2003) found a strong positive relationship between IS playfulness, perceived ease of use, and the intention to creatively use an IS. The absence of intrinsic motivation has been found to impede creative processes when using an IS. For instance, Elam and Mead (1990) suggested that if an IS is not intrinsically perceived to be enjoyable and easy to use it will hamper creative processes. This leads to the following proposition:

P3: The lack of intrinsic motivation to use a centralized IS will impede organizational creativity.

\section{I.1.2. Supervisory encouragement}

User involvement in IS adoption is largely suggested to be the main factor in increasing creative processes (Baroudi et al., 1986; Cooper, 2000). Involvement will lead users to develop a better understanding of an IS. Users will be more inclined to creatively use an IS and to be more satisfied with it (Baroudi et al., 1986). Involvement 
may lead to improved IS quality as well as increased user acceptance, reflected in increased satisfaction with the IS (Ives and Olson, 1984). The role of management is crucial to involve users and to increase the creative use of an IS (Baroudi et al., 1986). Top management must formulate and communicate the vision behind the implementation of an IS, and through their managers, should create a sense of mission among users (Cooper, 2000). Top management must view the organization not merely as an economic entity whose efficiency is based on process rationalization but also as a social system consisting of individuals trying to cope with the sweeping changes occasioned by the new IS (Sarker and Lee, 1999). Managers need to create an environment where users feel appreciated and to make careful use of reward and recognition systems to encourage IS adoption and its creative use (Stenmark, 2005). If managers are inclined too tightly to procedures, users may resist adopting an IS and lose the benefits of its creative use (Sarker and Lee, 1999). For example, monitoring, penalties, and censoring undermine creative processes when using an IS (Stenmark, 2005). This leads to the following proposition:

P4: The lack of supervisory encouragement to involve users in a centralized IS adoption will impede organizational creativity.

\section{I.1.3. Group creativity support}

IS research has largely suggested that facilitating group creativity through IS use is necessary to enhance organizational creativity (Nunamaker et al.,
1987; Ocker et al., 1995). Advances in technology, network communication, shared databases, and collaborative network tools have favored an environment where the opportunity for interactivity using an IS is technically possible (Nunamaker et al., 1987). Technical feasibility, however, does not ensure that an IS will be effective in promoting collaboration to support group creativity (Nunamaker et al., 1987). Group creativity can be facilitated through IS use when managers allow group members to work collaboratively to capitalize on their diverse knowledge and skills, clarify and ensure commitment of members to group objectives, manage conflict effectively, and develop intra-group safety and reflexivity (Cooper, 2000). The context of the work group has been found to affect the group's creativity process (Nunamaker et al., 1987). If managers fail to provide a climate of trust and if they fail to carefully manage group diversity, group members will be demotivated to collaborate, which hampers creative processes through IS use (Brown et al., 2004). This leads to the following proposition:

P5: The lack of group creativity support through the use of a centralized IS will impede organizational creativity.

\section{I.2. Available resources}

\section{I.2.1. Sufficient resources}

IS research emphasized the role of resources, such as training, technological infrastructures, and funds in IS adoption and its creative use (Alavi and Joachimsthaler, 1992; Davis and Davis, 1990). Training refers to the 
provision of hardware and software skills sufficient to enable effective interaction with the IS (Alavi and Joachimsthaler, 1992). When users are satisfied with support for their training needs and with the development requirements, they will be motivated to use an IS and to engage in creative processes to perform their activities (Davis and Davis, 1990). Attention to individual differences in training needs and training choices are suggested to ensure the effective training necessary for developing technical and creative skills (Colquitt et al., 2000). The lack of appropriate resources has been found to impede the adoption of an IS and its potential use for creative processes (Sarker and Lee, 1999). This leads to the following proposition:

P6: The lack of sufficient resources to use a centralized IS will impede organizational creativity.

\subsubsection{Time pressure}

Few studies examined the effects of time pressure on creative processes using IS (Paul and Nazareth, 2010). Some studies found that a certain degree of time pressure can have a positive influence, if it is perceived as arising from intellectually challenging activities. For instance, Gray and Durcikova (2005) suggested that when facing higher levels of work-related time pressure, learning oriented users will use an IS to source more knowledge, thus increasing their creative processes. Nevertheless, there is some evidence that excessive time pressure is expected to undermine creative processes by decreasing users' motivation to source and share knowledge through an IS (Paul and Nazareth, 2010). Studies suggested that when the time required to process information exceeds the available time, information overload occurs creating a stressful situation that impedes creative processes (Ahuja and Thatcher, 2005). This leads to the following proposition:

P7: Excessive time pressure will impede organizational creativity when using a centralized IS.

\section{I.3. Management practices}

\section{I.3.1. Autonomy and freedom}

Autonomy fosters creativity because it gives people freedom in how they approach their activities, heightens their intrinsic motivation, and increases their sense of challenge (Ahuja and Thatcher, 2005). Creativity is fostered when organizational members have the needed autonomy in carrying out their activities (Zhou, 1998). In contrast, an organizational climate in which individuals are subject to systematic monitoring impedes creative processes (Amabile, 1988). Individuals are likely to perceive such practices as controlling, which lowers the intrinsic motivation to think and act creatively. Wood (1998) suggested that if managers use the IS to monitor subordinates by tracing, supervising, and recording evidence, they will create a climate of mistrust that hampers local initiatives. Furthermore, the control of structures through restricted or password-protected areas will also impede creative processes and decrease organizational creativity (Curry and Stanci- 
ch, 2000). This leads to the following proposition:

P8: The lack of users' autonomy to freely act on information using a centralized IS will impede organizational creativity.

\section{I.3.2. Organizational impediments to creativity}

IS research suggested that conservatism, and rigid and formal management culture impede creative processes (Cooper, 2000; Sarker and Lee, 1999). Because users are likely to perceive each of these factors as an additional constraint to the inflexibility imposed by centralized IS structures, they will feel less autonomous and thus less intrinsically motivated to creatively use an IS for their activities (Sarker and Lee, 1999). This leads to the following proposition:

P9: Conservative organizational culture will impede organizational creativity when using a centralized IS.

The propositions will be used to explain how Schneider Electric failed to enable organizational creativity through its centralized intranet.

\section{RESEARCH METHOD}

Case research method is well-suited to our study, since the object of our discipline is IS in organizations, where interest shifted to organizational rather than technical issues (Benbasat et al., 1987). The case study of Schneider Electric provides an opportunity to investigate in a real-life setting the organizational factors that can inhibit orga- nizational creativity through a centralized system (Yin, 2003). Case research is widely used in a positivist perspective for generating propositions, providing explanations and testing hypotheses (Lee, 1989; Sarker and Lee, 2002; Yin, 2003). Two main reasons motivated us to adopt a positivist case research. First, it represents the dominant paradigm in IS case research (Dubé and Paré, 2003). Second, early recommendations formulated by researchers are most suitable to the positivist paradigm (Benbasat et al., 1987). The adoption of a positivist perspective is accompanied by a broad commitment to the idea that the social sciences should emulate the natural sciences (Lee 1989). Epistemologically, positivist studies are premised on the existence of fixed relationships within phenomena capable of being identified and "tested" via descriptive analysis (Dubé and Paré, 2003). Using descriptive case research, we attempted no theoretical interpretation of the phenomena; rather, we presented what we believe to be straightforward, objective, factual accounts of events to illustrate some issues (Sarker and Lee, 2002) related to the intranet failure at Schneider Electric. Employing a positivist case research requires attention to construct validity, reliability, and external validity (Dubé and Paré, 2003).

Construct validity is supported by multiple data collection methods based on the triangulation approach (Benbasat et al., 1987; Yin, 2003). Collected data included business documents (annual reports and promotional material), and internal documents (company newsletters, corporate intranet strategy, and the intranet project model). We 
also collected data from participants about their interpretations of events and processes, and these data are assumed to reasonably reflect external reality (Kirk and Miller, 1986). A total of 31 semi-structured interviews, conducted between 2006 and 2010 each lasting about an hour and a half, were conducted with participants from several departments within the company (see Table 1). The participants were selected based on two criteria: (1) they had been leaders of, or involved in, the decision making processes that shaped intranet implementation and use; and (2) they were capable of evaluating the shared perceptions of their services regarding intranet implementation and use.

Construct validity is also supported by feedback on a draft of this article from key company informants in particular managers in charge of the communication and IT departments. They provided us with helpful comments that confirmed the issues that were identified.

Reliability is demonstrated by the appropriate use of the case study protocol (Yin, 2003). Data collection at the company primarily took place over a five-month period. The interviews were comprised of 27 semi-structured questions addressing five main themes, as suggested by Cooper (2000): an overview of the user's roles and responsibilities, a description of the centralized IS (intranet), key players, organizational climate factors and how they influenced organizational creativity, and what went well and what went wrong with the IS. Each interview was

\begin{tabular}{|c|c|c|}
\hline Participants & Departments & Descriptions \\
\hline $\begin{array}{l}\text { - } 1 \text { employee (lead user) } \\
-4 \text { managers (user requirements and } \\
\text { intranet implementation) }\end{array}$ & $\begin{array}{l}\text { Technical } \\
\text { department }\end{array}$ & $\begin{array}{l}\text { New product development. Regroup- } \\
\text { ing R\&D services, product and quali- } \\
\text { ty services, and design and produc- } \\
\text { tion services. }\end{array}$ \\
\hline $\begin{array}{l}\text { - } 2 \text { Directors (project coordinators in } \\
\text { the steering committee) } \\
-7 \text { managers (user requirements and } \\
\text { intranet implementation) }\end{array}$ & $\begin{array}{l}\text { Commercial } \\
\text { department }\end{array}$ & $\begin{array}{l}\text { New offer development. Regrouping } \\
\text { marketing, communication, and sales } \\
\text { services }\end{array}$ \\
\hline $\begin{array}{l}-9 \text { Directors (project coordinators in } \\
\text { the steering committee) }\end{array}$ & $\begin{array}{l}\text { Operational } \\
\text { department }\end{array}$ & $\begin{array}{l}\text { Production and manufacturing. Re- } \\
\text { grouping business services, method } \\
\text { and fabrication services, order pro- } \\
\text { cessing services, and contract pro- } \\
\text { cessing services. }\end{array}$ \\
\hline $\begin{array}{l}\text { - } 6 \text { Directors (project coordinators in } \\
\text { the steering committee) }\end{array}$ & $\begin{array}{l}\text { Administrative } \\
\text { department }\end{array}$ & $\begin{array}{l}\text { Process management. Regrouping } \\
\text { HR services, accounting, and shared } \\
\text { services center. }\end{array}$ \\
\hline - 2 Directors (project managers) & IT department & $\begin{array}{l}\text { Software development. Regrouping } \\
\text { customer software and business ser- } \\
\text { vices and IT services. }\end{array}$ \\
\hline
\end{tabular}

Table 1: Participants and department characteristics 
transcribed to a word processor, with its date, time, and codes related to the conceptual model as well as any reflective remarks (Miles and Huberman 1984).

The interviews were coded by content analysis as recommended by Krippendorff (1980) using concepts related to the perceptual categories of work environment factors affecting organizational creativity, as presented in Figure 1. The Sphinx Lexica software was used to extract from each interview all citations $^{1}$, i.e., verbatim, related to stimulant and obstacle factors that influenced organizational creativity through the centralized intranet. Table 2 presents the results of the content analysis approach employed in the present study. The content analysis shows that obstacle factors seem to outweigh stimulant factors. In the following section, we describe the obstacle factors to explain the centralized intranet failure to enable organizational creativity at Schneider Electric.

\section{RESULTS}

\section{III.1. Schneider Electric and its centralized corporate intranet}

Schneider Electric is a leading French global electricity and automation management company. It operates in an intensely competitive environment that continuously threatens to erode its market share and negatively impact its financial performance. In response to these competitive pressures, Schneider
Electric strives to anticipate its clients' needs to maintain competitive advantage. A critical success factor in achieving that goal is believed to be innovation in products and information technology-enabled processes, as expressed by its CEO: "When we give talented and imaginative teams the opportunity to work together, it is always fertile (...) the coming years should give priority to innovation and technology in all our specialties."

The company combines the need to innovate with strategies for organizational change and was seeking to eliminate departmental boundaries and streamline its workflows. Therefore, the decision to implement a new centralized intranet had substantial management support because it fits well with the company's priorities. Historically, the intranet at Schneider Electric operated in two major periods: period 1 (1980 - 1990) a decentralized intranet arising from a grassroots initiative and period 2 (since 2004) a centralized corporate intranet run as a controlled process.

\section{III.1.1. Period 1: Decentralized intranet as grassroots initiative}

Managers in several departments began developing a decentralized intranet consisting of a few internal websites on the corporate network that enabled them to collaborate. Within the departments, managers encouraged their collaborators to be creative and to manifest their skills for creating websites, web-boards and links useful

\footnotetext{
${ }^{1}$ Citations in the text are extracted from semi-structured interviews conducted between 2006 and 2010.
} 


\begin{tabular}{|c|c|c|c|c|c|c|c|}
\hline 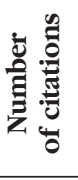 & i & 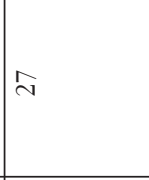 & $\stackrel{n}{\sim}$ & $\vec{\sim}$ & ஜิ & $\vec{n}$ & ㄴ \\
\hline 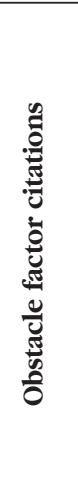 & 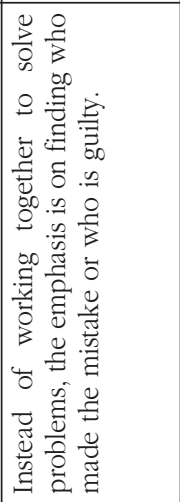 & 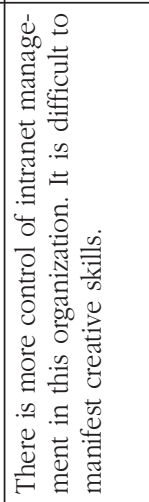 & 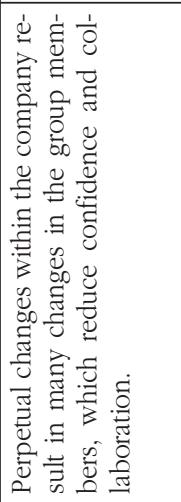 & 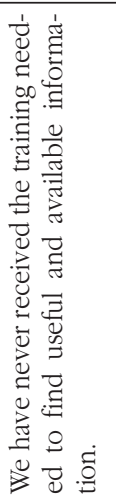 & 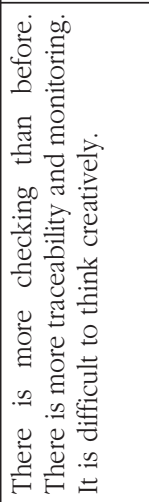 & 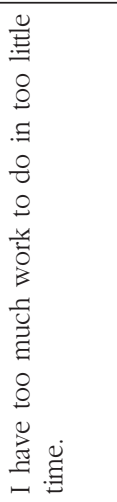 & 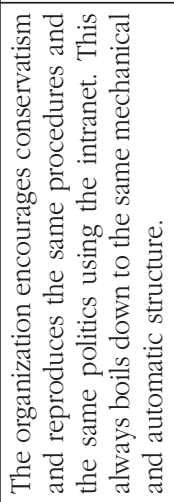 \\
\hline 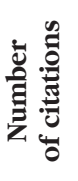 & in & $\forall$ & 0 & $\stackrel{\circ}{\simeq}$ & $\exists$ & 1 & 1 \\
\hline 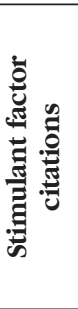 & 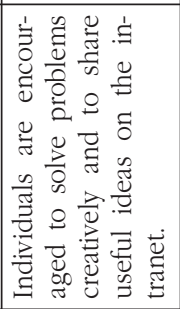 & 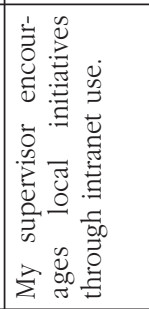 & 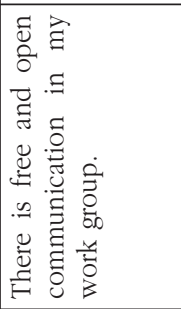 & 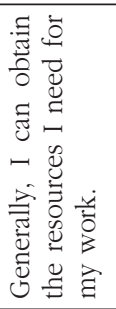 & 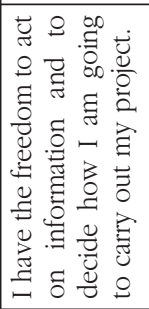 & 1 & 1 \\
\hline 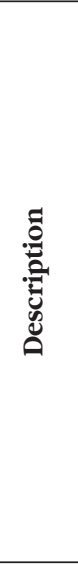 & 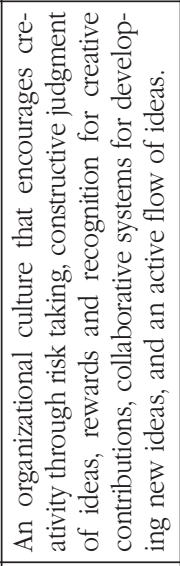 & 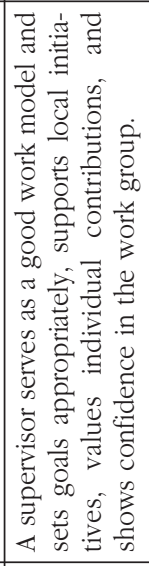 & 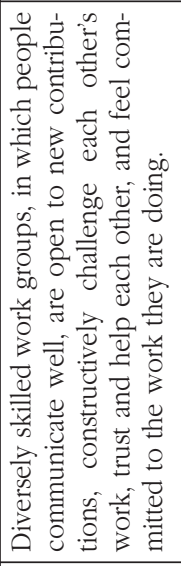 & 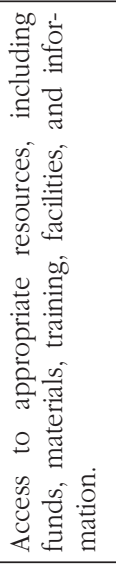 & 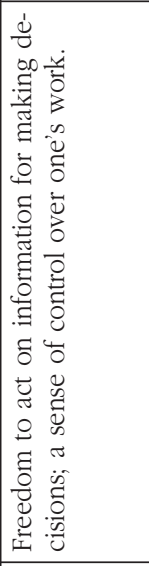 & 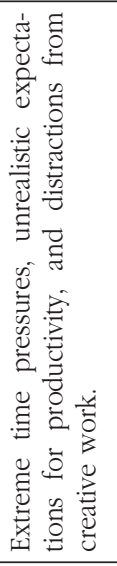 & 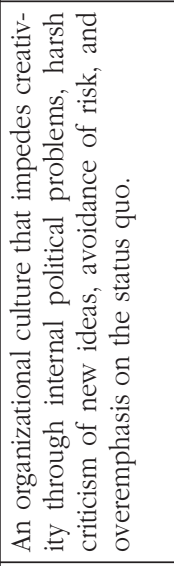 \\
\hline 总 & 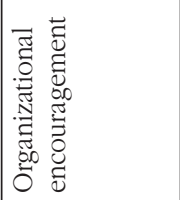 & 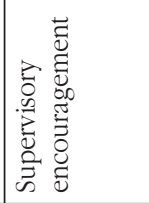 & 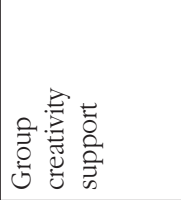 & 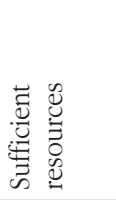 & 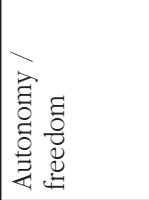 & 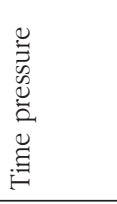 & 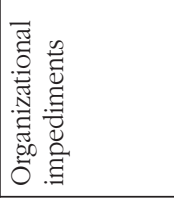 \\
\hline
\end{tabular}


for collaboration. Thus, openness toward local initiatives encouraged positive attitudes about intranet use. It quickly became evident that the intranet initiative had gained many supporters.

Employees in several departments were thus actively developing the intranet, as indicated by the rapid growth in the number of websites and web-boards. "The intranet was an absolutely extraordinary success; it was seen by some as a technology that saved our life" (IT Department Director). The number of websites created was estimated at over 150, without counting the great number of webboards and applications created. All websites and services belonged to the information owners who were usually senior managers or department managers. Every information owner in each department ensured that the published information was valid and updated. The information owners supervised the web users, who were usually collaborators trained in setting up, maintaining, and updating websites. The web users were also in charge of helping users in each department to publish their useful information or to create helpful applications. While departments were responsible for maintaining their own websites, the more advanced services, such as videoconferences, audio-conferences, and the corporate telephone directory, were typically developed by the IT department. The IT department specializes in solutions based on web technology, hardware, software, installation, training, management of basic infrastructure, and user support. The decentralized intranet was observed as a "creative support because we had the freedom to act... We had the motivation to use it" (Contracts Manager). Although the intranet was perceived as easy to use, "the absence of a web search engine made access to local sites and information difficult, which made interdepartmental collaboration also difficult' (Vice President of Customer Software and Business). To find needed information, employees improvised by exploring useful links and sharing practical ideas through discussion forums. Although these practices led to lost time, they were essentially observed as "stimulating individual creativity because they enhanced discovery" (Marketing Manager). Formal documents were stored and distributed through the intranet using a document management system, and a number of simple workflow applications allowed employees to consult documents and library books. Many of these tools were experimental as individuals explored the potential of the technology, but they were frequently used due to their perceived usefulness. To summarize, the first period was characterized by exploratory attitudes about the technology, a commitment to learning by doing, and openness toward local initiatives. The liberal "free-for-all practices stimulated organizational creativity and created a large community of active users." (Methods and Fabrication Manager)

\section{III.1.2. Period 2: Centralized corporate intranet as a controlled process}

As a means of implementing radical change in a traditional organization, 
Schneider Electric decided to centralize its intranet to react more quickly and efficiently to its challenges. The primary goal was to eliminate departmental boundaries and job descriptions and thereby to streamline workflows. The company also sought to rationalize its activities and focus on core functions by reducing all costs and investments. An important part of the transformation was to remove barriers to information sharing and improve intra and inter-departmental communication and collaboration. The centralized intranet project was approved by top management, who embraced its concept from the beginning and allocated the necessary resources to its development. Top management considered the centralized intranet as the best way to implement the new management philosophy. The proposed centralized corporate intranet was expected to evolve traditional websites toward a single backbone network providing all departments with a single mechanism to disseminate information, support collaboration, and enhance creativity and learning. The project was championed by the Vice President of Customer Software and Business and carried out by the corporate IT department. The top management decided to adopt a "topdown approach emphasizing careful planning and management control' (IT Department Director). The Vice President acted as the organizational intranet sponsor and had the overall responsibility for the centralized intranet initiative in relation to the company strategy. In addition, three new organizational roles were created: Web Coordinator, Web Developer, and Content Provider.

\section{III.2. Declaring the centralized corporate Intranet "a failure"}

The Vice President aimed to enhance intra and inter-departmental collaboration through the intranet. The decision to impose its use was firm. It was implemented on time and within budget. As a centralized system, it directed queries toward the various sources of practical information; the local websites, which belonged to each department, and put collections of information, documents, tools, databases, and application tools at the disposal of all employees. The application tools were for the most part collaborative tools managed by specific software to enable virtual meetings and remote collaboration.

Despite significant management support and user contribution, the Vice President believes this project to be his "greatest failure." The main indicator was the decrease in intranet use within the departments. In the view of the Vice President, Schneider Electric failed to take advantage of intranet use to increase organizational creativity, which would have led to organizational change. This disappointment was expressed by many managers. They had a "feeling of reserve about the intranet use because the employees perceived it as mere substitute to their habitual work practices" (IT Department Director) and as "a support for increasing traceability and monitoring" (Human Resources Manager), which meant "the system was less used" (Manager of Order Processing). "The intranet was not appropriate for exchanging useful ideas and best practices; we would have needed to make a big effort in this sense. Our in- 
tranet was poor and our practices didn't sufficiently promote contributions for improving the content" (Contracts Manager). This resulted in dissatisfaction and feeling that no "process change" had occurred (Manager of Order Processing).

Because the centralized intranet was a failure, we next review the present case in terms of propositions discussed in the previous section, to understand what climate factors were absent and how the system failed to enable organizational creativity.

\section{III.3. Encouragement of creativity}

\section{III.3.1. Organizational encouragement}

Risk taking: For creativity to occur, "there is a need to accept risk taking and the right to errors" (Human Resources Director). However, a relative "conservatism predominates at the company, preventing users from being creative" (Factory Production Manager). Therefore, "instead of working together to solve problems, we try to find out who made the mistake or who is guilty" (Export Sales Manager). This sent the message that "management is not interested in encouraging local initiatives" (Contracts Manager) and led to users' refusal to collaborate and share their ideas through the intranet. Furthermore, this feeling, expressed by a communication officer, was reinforced by the recent policy that required that "intranet use be justified in terms of significant cost reductions" (IT Department Director). Such emphasis on strict economic rationale provided little incentive for users to take risks and thus reduced the potential for organizational creativity.

Task Motivation: Intranet staff members found the new technology very interesting and believed that if users became familiar with it they would find it "belpful in their activities" (IT Department Director). Yet, although some users were intrigued by the intranet, none described it as potentially useful for their activities. The collaborative tools were poor and "very few people used them" (Contracts Manager). In addition, these tools "required substantial learning time, which was not available" (Human Resources Director). Therefore, a lack of time prevented users from enjoying the process of learning and exploring the intranet. In addition, the minimal perceived impact on activities associated with the difficulty of use further lowered employee efforts regarding the intranet, thereby reducing the potential for organizational creativity.

\section{III.3.2. Supervisory encouragement}

Creativity in practice is driven by a "managerial culture that rewards new ideas, allows risk taking, authorizes errors, and encourages those who have made new things" (Human Resources Director). In the company "nothing concrete and explicit was really implemented to encourage the creativity of collaborators" (Contracts Manager). Further, a recent policy that required "more control of intranet management in order to rationalize practices and improve productivity" (Vice President of Customer Software and Business) only reinforced monitoring practices, 
and certain managers even prohibited the use of forums and considered them "unproductive" when they were used for nonprofessional concerns (Contracts Manager). Furthermore, users were "rewarded based on their current jobs" (Human Resources Director), with no obvious incentives for creative contributions. For example, in the Method and Fabrication service, certain users known as "innovators" devoted considerable time, in addition to their workload, to share their useful ideas through web-boards to help the group's members resolve technical problems. Yet, none had their normal workload decreased or received financial rewards. This sent a message that "management was not really interested in creativity", which resulted in less use of collaborative tools (Factory Production Manager). The lack of encouragement prevented user commitment, again reducing the potential for organizational creativity.

\section{III.3.3. Group creativity support}

Schneider Electric has a history of continuous changes: "the company is constantly going through changes" (Shared Services Center Manager) and "we reorganize every 12 to 24 months" (Export Sales Manager). This type of upheaval means frequent changes in group members, which limits the confidence within groups necessary to elicit useful contributions. For example, " $a$ new manager was appointed to head a sales team; he made changes in the team members' practices by using intranet functionalities to trace and record evidence" (Human Resources Director). These practices created a cli- mate of mistrust, which reduced team creativity and collaboration. One reason for this was the fear of making mistakes in a climate that was characterized by "more monitoring" (Human Resources Director). Out of mistrust, people made fewer contributions and this reduced the likelihood of enabling organizational creativity through intranet.

\section{III.4. Available resources}

\section{III.4.1. Sufficient resources}

Material resources and funds were allocated for the successful development of the intranet at Schneider Electric. All users were equipped with PCs, and the IT department built the technical infrastructure by installing browsers on all PCs, thereby increasing the capacity of the existing corporate network and adding more international connections to it. However, the intranet staff members believed that "training is no longer a main concern because the intranet has been around for a while now and it will be used either because it is imposed from above through the hierarchy or in tacit acknowledgement that it's essential to our activities" (Vice President of Customer Software and Business). In addition, the decision to "force" users to adopt the intranet without training had a deleterious effect on the supportive atmosphere, which resulted in communications that were "manipulated" (Factory Production Manager) and reduced the likelihood of organizational creativity.

\section{III.4.2. Time pressure}

Organizational practices at Schneider Electric are based on management by 
objectives and "a lot of time pressure and stress" prevented employees from using collaborative tools for sharing useful ideas (Manager of Procurement Processes). Furthermore, although electronic mail was the main collaborative tool, the high number of messages caused an information overload, which in turn became an "impediment" for organizational creativity (Operations Unit Manager).

\section{III.5. Management practices}

\section{III.5.1. Autonomy or freedom}

Practices were based on an "excessively" rigorous control of management processes (Export Sales Manager, Marketing Information Systems Manager). "Users had little autonomy to act freely on information because the intranet was managed by a web-coordinator" (Marketing Information Systems Manager). In addition, directors in certain departments preferred controlling information through restricted access and password-protected areas, which also reduced contributions (Contracts Manager). Furthermore, "certain managers used electronic mail for tracing and recording evidence," which prevented collaboration (Shared Services Center Manager), thereby reducing the potential use of intranet to enhance organizational creativity.

\section{III.5.2. Organizational impedi- ments to creativity}

Because of significant growth in the company, a relatively "conservative culture" had come to predominate (Technical Services Manager). The re- cent policy requiring "more control" (Factory Production Manager) created negative perceptions about the intranet that was perceived as an additional mean to "encourage conservatism and reproduce the same procedures and the same directives" (Human Resources Manager). This feeling was reinforced by the conviction that "creativity comes from upstream" (Operations Unit Manager), which prevented creative downstream contributions and reduced the likelihood of organizational creativity.

\section{DISCUSSION AND CONCLUSION}

Organizations can learn important lessons from their failures as well as their successes, and learning from a failure is more likely to be beneficial for leading to a success (Sarker and Lee, 1999). The "failure story" provided in our study is an interesting lesson that illustrates problems associated with enabling organizational creativity through a centralized IS. Organizational creativity was operationalized in terms of creative processes facilitated by information sharing and organizational learning. A centralized IS can enhance creative processes but requires an appropriate climate (Cooper, 2000). Our study sheds light on characteristics of organizational climate that should be avoided to enhance organizational creativity through a centralized IS. A creativity model based on the componential creativity theory (Amabile, 1988; 2013) was adapted and used to understand how Schneider Electric failed to enable organizational creativity through its centralized intranet. 
There are four main issues that negatively impacted organizational creativity through the intranet at Schneider Electric. The first involves the operationalization of organizational creativity. Creativity literature distinguishes between organizational creativity and innovation. Organizational creativity corresponds to a new idea about a program, product, service, or process and depends on individuals working together in a creative climate (Woodman et al., 1993), while innovation corresponds to the successful implementation of such idea to achieve economic performance (Amabile et al., 1996). At Schneider Electric, the management objectives to foster innovation was tied to economic results without reconsidering creative processes, which explains the gap between expected and achieved results as illustrated by the intranet considered as a "greatest failure."

The second issue concerns the organization with regard to organizational creativity. Top management aimed to enhance creative processes through intranet use but no effective actions were communicated to encourage users' commitment. Top management has appointed the Vice President who acted as a transformative leader and applied a top-down management approach without involving users in the implementation process. This management approach created a climate of frustration among users who considered the intranet a substitute for their habitual work practices and an additional monitoring tool, which explains their reserve to use it. It is, therefore, clear that the resulting IS does not enable creative processes as intended.
The IS literature highlighted this issue and stated that most centralized IS failures stem from the breakdowns in IS leadership (Cooper, 2000; Sarker and Lee, 1999; Stoddard and Jarvenpaa, 1995). A partnership between IS leadership and users is considered a key to successful innovation (Davenport and Stoddard, 1994). Top management support as encompassing both participation and involvement is also considered necessary for successful innovation (Grover et al., 1995; Stoddard and Jarvenpaa, 1995). Top management must formulate and clearly communicate intentions and through transformative leadership, create a sense of mission among all users (Cooper, 2000). Communication between top management and the employees is necessary to clarify the vision and corporate strategy, address the need, scope, and commitment to the project (Grover et al., 1995). Communication and commitment building must occur at all levels and for all users (Davenport and Stoddard, 1994). Regular communication must be established between top management and IS leadership as well as between IS leadership and project teams and those who will be affected by the new IS (Grover et al., 1995). Top management must view the organization not only as an economic entity but also as a social system consisting of users trying to cope with sweeping changes occasioned by the new centralized IS (Sarker and Lee, 1999).

The third issue concerns IT management with regard to organizational creativity. Although substantial funds were allocated for the successful deployment of the centralized intranet, 
users considered the intranet as useless and difficult to use. The multiplicity of interfaces made the system unappealing and demotivated users to take advantage of its potential to engage in creative contributions. Further, the lack of training prevented users from developing the necessary skills to explore the system and to increase users' motivation (Bostrom et al., 1990). Perceived time pressure and information overload appeared to be an additional barrier to learning, which impeded creative use of the system (Ahuja and Thatcher, 2005).

The last issue concerns management practices with regard to organizational creativity. The centralized IS has unveiled hidden management practices inclined to excessive control and monitoring. The centralized intranet has limited users' autonomy by reinforcing malicious practices through tracing and recording evidence, which generated a climate of mistrust hampering information sharing and learning. At Schneider Electric, there was no management support to promote best practices through IS use. Managers need to make careful use of "signals" (e.g., clear and explicit messages to avoid malicious practices and to encourage good practices), "symbols" (e.g., actions that reinforce the signals such as prohibiting malicious uses), and "reward systems" (e.g., recognition and reward of good practices) (Sarker and Lee, 1999; Stenmark, 2005).

From a theoretical perspective, our study makes several contributions. First, it focuses on the relationship between organizational creativity and centralized IS, a topic that received little attention in the IS literature. Al- though the IS literature recognizes the role of centralized IS as potential for organizational creativity, studies illustrating why these systems failed in certain contexts, remain scarce. Our case study provides an interesting "failure story" to shed light on these issues. Second, although a rich literature has increased our knowledge of a firm's choice of a centralized IS (Brown, 1997; Brown and Magill, 1994; Sambamurthy and Zmud, 1999), little has been done to explain how these systems can be used to support organizational creativity. Our study conceptualizes the perspective that a centralized IS can bring efficiency and control but requires an appropriate climate to enable organizational creativity. Last, our study develops a creativity model based on the componential creativity theory and offers useful propositions that can be replicated in other contexts for future research.

From a practical perspective, given the key role of organizational creativity and centralized IS for innovation, this article provides an illustration of organizational climate factors that should be avoided to enhance organizational creativity. Managing creativity is a complex process that requires a good grasp of organizational climate to promote it (Amabile, 2013). Insights provided in our research can help organizations to reconsider the balance between stimulating creativity and increasing management control through a centralized IS. IS leadership is a legitimate player that can restore this balance when implementing a centralized IS (Khalil and Dudezert, 2014). Our study suggests that leaders should rethink their organization, IT manage- 
ment, and management practices to favor an appropriate climate and to foster facilitating organizational creativity (Dewett, 2003).

Beyond problems related to descriptive case research such as its lack of generalizability and its contextbound nature (Baskerville and WoodHarper, 1996), our study has two main limitations that should be overcome to improve future studies. First, data was collected after intranet implementation which may lead to biases. To further address this potential issue and to control for events in real time it will be useful to collate data before and after intranet implementation (Sarker and Lee, 1999). Second, the data collection instrument makes use of individual perceptions about intranet use. Perceptions may lead to biases when data is collected at the same point in time. To overcome this issue and to increase the validity of results, future research should be done using longitudinal approaches (Kirk and Miller, 1986). Despite these limitations, our research provides interesting implications for research and practice. The propositions adapted from the componential theory of creativity are far from unassailable, and therefore should be replicated in future research and tested quantitatively in other contexts.

\section{REFERENCES}

Agarwal, R., Prasad, J. (1998), “ A conceptual and operational definition of personal innovativeness in the domain of information technology ", Information Systems Research, Vol. 9, $\mathrm{n}^{\circ}$ 2, p. 204215.
Ahuja, M.K., Thatcher, J.B. (2005), “ Moving beyond intentions and toward the theory of trying: Effects of work environment and gender on post-adoption information technology use ", MIS Quarterly, Vol. 29, n³, p. 427-459.

Ajzen, I., Fishbein, M. (1980), Understanding attitudes and predicting social behaviour, Prentice-Hall, Englewood Cliffs, NJ.

Alavi, M., Joachimsthaler, E.A. (1992), " Revising DSS implementation: A meta-analysis of the literature and suggestions for researchers ", MIS Quarterly, Vol. 16, $\mathrm{n}^{\circ} 1$, p. 185-201.

Amabile, T.M. (1988), "A model of creativity and innovation in organizations " in Research in Organizational Behavior, B. Staw and L.L. Commungs (Eds), JAI Press Inc., Greenwich, Conn, p. 123-167.

Amabile, T.M. (2013), "Componential theory of creativity " in Encyclopaedia of Management Theory, E.H. Kessler (Eds), SAGE Publications, Thousand Oaks, CA, p. $135-140$.

Amabile, T.M., Conti, R., Coon, H., Lazenby, J., Herron, M. (1996), "Assessing the work environment for creativity ", Academy of Management Journal, Vol. 39, $\mathrm{n}^{\circ} 5$, p. 1154-1184.

Bansler, J.P., Damsgaard, J., Scheepers, R., Havn, E., Thommesen, J. (2000), "Corporate intranet implementation: Managing emergent technology and organizational practices ", Journal of the Association for Information Systems, Vol. 1, $\mathrm{n}^{\circ} 1$, p. 139.

Baroudi, J.J, Olson, M.H., Ives, B. (1986), "An empirical study of the impact of user involvement on system usage and information satisfaction ", Communication of ACM, Vol. 29, n 3, p. 232-238.

Baskerville, R.L., Wood-Harper, A.T. (1996), "A critical perspective on action research as a method for information 
systems reseach ", Journal of Information Technology, Vol. 11, p. 235-246.

Benbasat, I., Goldstein, D., Mead, M. (1987), "The case research strategy in studies of information systems ", Management Information Systems Quarterly, Vol. 11, n³, p. 369-386.

Benbya, H., Meissonier, R. (2007), "La contribution des Systèmes de Gestion des Connaissances au développement de nouveaux produits: étude de cas d'une entreprise du secteur de l'industrie aeronautique ", Systèmes d'Information et Management, Vol. 12, $\mathrm{n}^{\circ} 1$.

Bloomfield, B.P., Coombs, R. (1992), "Information technology, control and power: The centralization and decentralization debate revisited ", Journal of Management Studies, Vol. 29, $\mathrm{n}^{\circ} 4$, p. 459-484.

Bostrom, R.P., Olfman, L., Sein, M.K. (1990), "The importance of learning style in end-user training ", MIS Quarterly, Vol. 14, $\mathrm{n}^{\circ} 1$, p. 101-119.

Brown, C.V. (1997), "Examining the emergence of hybrid IS governance solutions: Evidence from a single case site ", Information System Research, Vol. 8, $\mathrm{n}^{\circ} 1$, p. 69-94.

Brown, C.V., Magill, S.L. (1994), "Alignment of the IS functions with the enterprise: Toward a model of antecedents ", MIS Quarterly, December, p. 371-403.

Brown, H.G., Poole, M.S., Rodgers, T.L. (2004), " Interpersonal traits, complementarity, and trust in virtual collaboration ", Journal of Management Information Systems, Vol. 20, n 4, p. 115-137.

Colquit, J.A., LePine, J.A., Noe, R.A. (2000), "Towards an integrative theory of training motivation: A meta-analytic path analysis of 20 years of research ", Journal of Applied Psychology, Vol. 85, $\mathrm{n}^{\circ} 5$, p. 687-707.
Cooper R.B. (2000), "Information technology development creativity ", MIS Quarterly, Vol. 24, $\mathrm{n}^{\circ} 2$, p. 245-276.

Curry, A., Stancich, L. (2000), "The intranet - an intrinsic component of strategic information management? ", International Journal of Information Management, Vol. 20, n 4 , p. 249-268.

Davenport, T.H., Stoddard, D.B. (1994), " Reengineering: Business change of mythic proportions? ", MIS Quarterly, Vol. 18, n², p. 121-127.

Davis, D.L., Davis, F.D. (1990), "The effect of training techniques and personal characteristics on training end users of information systems ", Journal of Management Information Systems, Vol. 7, $\mathrm{n}^{\circ} 2$, p. 93-110.

Davis, F.D. (1989), "Perceived usefulness, perceived ease of use, and user acceptance of information technology ", MIS Quarterly, Vol. 13, n³, p. 319-340.

Davis, F.D., Bagozzi, R.P., Warshaw, P.R. (1992), "Extrinsic and intrinsic motivation to use computers in the workplace ", Journal of Applied Social Psychology, Vol. 24, n 14, p. 1111-1132.

Deci, E.L., Ryan, R.M. (1985), Intrinsic motivation and self-determination in human behavior, Plenum Press, New York.

Dewett, T. (2003), "Understanding the relationship between information technology and creativity in organizations ", Creativity Research Journal, Vol. 15, n 2/3, p. $167-182$.

Dewett, T. (2007), " Linking intrinsic motivation, risk taking, and employee creativity in an R\&D environment ", RED Management, Vol. 37, $\mathrm{n}^{\circ}$ 3, p. 197-208.

Dubé, L., Paré, G. (2003), "Rigor in information systems positivist case research: Current practices, trends, and recommendations ", MIS Quarterly, Vol. 27, $\mathrm{n}^{\circ} 4$, p. 597-635. 
Elam, J.J., Mead, M. (1990), "Can Software Influence Creativity? ", Information Systems Research, Vol. 1, $\mathrm{n}^{\circ} 1$, p. 1-22.

Garfield, M.J., Taylor, N.J., Dennis, A.R., Satzinger, J.W. (2001), " Research report: Modifying paradigms-individual differences, creativity techniques, and exposure to idea generation ", Information Systems Research, Vol. 12, $\mathrm{n}^{\circ} 3$, p. 322333.

Garud, R., Tuertscher, P., Van de Ven, A.H. (2013), "Perspectives on Innovation Processes ", The Academy of Management Annals, Vol. 7, $\mathrm{n}^{\circ} 1$, p. 775-819.

Gray, P.H., Durcikova, A. (2005), "The role of knowledge repositories in technical support environments: speed versus learning user performance ", Journal of Management Information Systems, Vol. 22, $\mathrm{n}^{\circ} 3$, p. 159-190.

Gray, P.H., Meister, D.B. (2006), “ Knowledge sourcing methods ", Information $\mathcal{E}$ Management, Vol. 43, p. 142-156.

Grover, V., Jeong, S R., Kettinger, W.J., Teng, J.T.C. (1995), "The implementation of business process reengineering ", Journal of Management Information Systems, Vol. 12, $\mathrm{n}^{\circ} 1$, p. 109-144.

Hackbarth, G., Grover, V., Yi, M. (2003), "Computer playfulness and anxiety: positive and negative mediators of the system experience effect on perceived ease of use ", Information \& Management, Vol. 40, p. 221-232.

Hwang, Y. (2005), "Investigating enterprise system adoption: Uncertainty avoidance, intrinsic motivation, and the technology acceptance model ", European Journal of Information Systems, Vol. 14, $\mathrm{n}^{\circ} 1$, p. $150-164$.

Ives, B., Olson, M. (1984), "User involvement and MIS success: A review of research ", Management Science, Vol. 30, $\mathrm{n}^{\circ} 5$, p. 586-603.
Jameux, C., Khedhaouria, A. (2009), "Créativité organisationnelle et usage de l'intranet chez Schneider Electric ", Systèmes d'Information et Mangement, Vol. 14, $\mathrm{n}^{\circ} 3$, p. 109-122.

Khalil, C., Dudezert, A. (2014), " Entre autonomie et contrôle : quelle régulation pour les systèmes de gestion des connaissances?", Système d'Information et Management, Vol. 19, $\mathrm{n}^{\circ} 1$.

Khedhaouria, A., Ribiere, V. (2013), "The influence of team knowledge sourcing on team creativity: Evidence from information system development ", The Learning Organization, Vol. 20, $\mathrm{n}^{\circ} 4 / 5$, p. 308-321.

Kim, L. (1998), "Crisis construction and organizational learning: capability building in catching-up at Hyundai Motor ", Organization Science, Vol. 9, $\mathrm{n}^{\circ} 4$, p. 506521.

King, J.L. (1983), "Centralized versus decentralized computing: Organizational considerations and management options ", Computing Surveys, Vol. 15, n०4, p. 320-349.

Kirk, J., Miller, M.L. (1986), Reliability and validity in qualitative Research, Sage Publications, CA: Beverly Hills.

Klein, K.J., Kozlowski, S.W.J. (2000), Multilevel theory, research and methods in organizations, San Francisco, CA: JosseyBass.

Krippendorff, K. (1980), Content analysis. An introduction to its Methodology, Sage, Beverly Hills.

Krueger, Jr. N., and Dickson, P.R.(1994), "How believing in ourselves increases risk taking: Perceived self-efficacy and opportunity recognition ", Decision Science, Vol. 25, n 3, p. 385-400.

Lee, A. (1989), "A scientific methodology for MIS case studies ", MIS Quarterly, Vol. 13, $\mathrm{n}^{\circ} 1$, p. 33-50. 
March, J.G., and Shapira, Z. (1987), “ Managerial perspectives on risk and risk taking ", Management Studies, Vol. 33, $\mathrm{n}^{\circ} 11$, p. $1404-1418$.

Massetti, B. (1996), "An empirical examination of the value of creativity support systems on idea generation ", MIS Quarterly, Vol. 20, $\mathrm{n}^{\circ} 1$, p. 83-97.

Miles, M.B., Huberman, A.M. (1984), Analyzing Qualitative Data: A Source Book for New Methods, Sage: Beverly Hills.

Mumford, M.D., Gustafson, S.B. (1988), "Creativity syndrome: Integration, application, and innovation ", Psychological Bulletin, Vol. 103, $\mathrm{n}^{\circ}$ 1, p. 27-43.

Nunamaker, J.F. Jr., Appelgate, L.M., Konsynski, B.R. (1987), "Facilitating group creativity: Experience with a group decision support system ", Journal of Management Information Systems, Vol. 3, $\mathrm{n}^{\circ}$ 4, p. 5-19.

Ocker, R., Hiltz, S.R., Turoff, M., Fjermestad, J. (1995), " The Effects of distributed group support and process structuring on Software requirements development teams: Results on creativity and quality ", Journal of Management Information Systems, Vol. 12, $\mathrm{n}^{\circ} 3$, p. 127-153.

Olson, M.H., Chervany, N.L. (1980). "The relationship between organizational characteristics and the structure of the information services function ", MIS Quarterly, Vol. 4, n², p. 57-68.

Paul, S., Nazareth, D.L. (2010), “ Input information complexity, perceived time pressure, and information processing in GSS-based work groups ", Decision Support Systems, Vol. 49, $\mathrm{n}^{\circ}$ 1, p. 31-40.

Ryan, R.M., Deci, E.L. (2000), "Intrinsic and extrinsic motivations: Classic definitions and new directions ", Contemporary Educational Psychology, Vol. 25, $\mathrm{n}^{\circ} 1$, p. 54-67.

Sambamurthy, V., Zmud, R.W. (1999), “ Arrangements for information technology governance: A theory of multiple contingencies ", MIS Quarterly, Vol. 23, n², p. 261-290.

Sarker, S., Lee, A. (1999), "IT-enabled organizational transformation: a case study of BPR failure at TELECO ", Journal of Strategic Information Systems, Vol. 8, $\mathrm{n}^{\circ}$ 1, p. 83-103.

Sarker, S., Lee, A.S. (2002), "Using a positivist case research methodology to test three competing practitioner theories-inuse of business process redesign ", Journal of the Association for Information Systems, Vol. 2, $\mathrm{n}^{\circ} 1$.

Satzinger, J.W., Garfield, M.J., Nagasundaram, M. (1999), "The creative process: The effects of group memory on individual idea generation ", Journal of Management Information Systems, Vol. 15, $\mathrm{n}^{\circ} 4$, p. $143-160$.

Seidel, S., Müller-Wienbergen, F., Becker, J. (2010), "The concept of creativity in the information systems discipline: Past, present, and prospects ", CAIS, Vol. 27, $\mathrm{n}^{\circ} 1$, p. $218-242$.

Sitkin, S.B., Pablo, A.L. (1992), "Reconceptualizing the Determinants of Risk Behavior ", Academy of Management Review, Vol. $17, \mathrm{n}^{\circ} 1$, p. 9-38.

Snow, T.A., Couger, D. (1991), "Creativity Improvement Intervention in a System Development Work Unit " in Proceedings of the Twenty-fourth HICSS, IEEE Computer Society Press, Washington, p. 412.

Stake, R.E. (1994), "Case studies " in Handbook of qualitative research, N.K. Denzin N.K. and Y.S. Lincoln (Eds), Sage, Thousand Oaks, California.

Stenmark, D. (2005), "Organizational creativity: Learning from a failing attempt to introduce IT support for creativity ", International Journal of Technology and Human Interaction, Vol. $1, \mathrm{n}^{\circ} 4$, p. 8098. 
Stoddard, D.B., Jarvenpaa, S.L. (1995), "Business Process Redesign: Tactics for change ", Journal of Management Information Systems, Vol. 12, $\mathrm{n}^{\circ}$ 1, p. 81-107.

Thompson, L. (2003), "Improving the creativity of organizational work groups ", Academy of Management Executive, Vol. 17, $\mathrm{n}^{\circ} 1$, p. 96-111.

Tiwana, A., McLean, E.R. (2005), "Expertise integration and creativity in information systems development ", Journal of Management Information Systems, Vol. 22, n 1, p. 13-43.

Tushman, M., O'Reilly III, C.A. (1996), "Ambidextrous organizations ". California Management Review, Vol. 38, $\mathrm{n}^{\circ} 4$, p. 8-30.

Van der Heijden, H. (2004), " User acceptance of hedonic information systems ", MIS Quarterly, Vol. 28, n 4, p. 695-704.
Von Simson, E.M. (1990), "The "centrally Decentralized' IS organization ", Harvard Business Review, Vol. 68, n 4, p. 158162.

Wood, A.M. (1998) “ Omniscient organizations and bodily observations: electronic surveillance in the workplace ", International Journal of Sociology and Social Policy, Vol. 18, n 5/6, p. 136-174.

Woodman, R.W., Sawyer, J.E., Griffin, R.W. (1993), "Toward a theory of organizational creativity ", Academy of Management Journal, Vol. 18, n ${ }^{\circ}$, p. 293-321.

Yin, R.K. (2003), Case study research, design and methods, Sage Publications, Newbury Park.

Zhou, J. (1998), " Feedback valence, feedback style, task autonomy, and achievement orientation ", Journal of Applied Psychology, Vol. 83, n² 2, p. 261-276. 


\section{AUTEURS}

Shamel Addas is an Assistant Professor of Management at the IESEG School of Management, France. He holds a PhD in Information Systems from McGill University. His current research interests include the individual- and group-level impacts of IT, IT-mediated interruptions, ITenabled knowledge management, and big data. His research has appeared in Information Systems Journal, Knowledge Management Research \& Practice, and AIS Transactions on Human-Computer Interaction. He has also presented his work at various academic conferences, including the Academy of Management, ICIS, AMCIS, HICSS, and ASAC.

Address : IESEG School of Management, 3 rue de la Digue, 59000 Lille, France

Mail: s.addas@ieseg.fr

Nassim Belbaly is Professor of Technology and Innovation Management. His current research interests are innovation management, new product development, Open Source Systems and design science research. He publishes in peer reviewed journals in IT management relative to his research fields.

Address: Groupe Sup de Co Montpellier Business School, 2300, Avenue des Moulins, 34185 Montpellier

Mail: n.belbaly@supco-montpellier.fr

Hind Benbya is Professor of Technology and Innovation Management. Her research and consulting consist in developing frameworks and tools for implementing and evaluating complex IT to support knowledge and innovative work (i.e., CoCreation Communities, Innovation Platforms \& Knowledge Management Systems). Her work has appeared in several practitioner and academic journals, including MIT Sloan Management Review, Information Technology and People, Journal of Information Technology, Communications of the AIS among others.
Address: Groupe Sup de Co Montpellier Business School, 2300, Avenue des Moulins, 34185 Montpellier

Mail: h.benbya@supco-montpellier.fr

Mickaël David holds $\mathrm{PhD}$ in information systems. He teaches information systems at the University of Angers. His current research interests are new product development, product lifecycle management systems and organizational routines. His doctoral work is in publication progress in several peer reviewed journals in management and information systems.

Address: Laboratoire d'Économie et de Management de Nantes-Atlantique, IEMNIAE Bâtiment Erdre, Chemin de la Censive du Tertre, BP 52231, 44322 NANTES Cedex 3, France.

Mail: mickael.david@univ-nantes.fr

Anis Khedhaouria is Assistant Professor of Technology and Innovation Management. He obtained his Ph.D. degree from the University of Savoy in Alpine Eastern France. His research interests include ITenabled creativity, creativity and innovation management, and Mobile Internet Services. He published in peer reviewed journals in IT management relative to his research fields.

Address: Groupe Sup de Co Montpellier Business School, 2300, Avenue des Moulins, 34185 Montpellier

Mail: a.khedhaouria@supco-montpellier.fr

Alain Pinsonneault, Fellow-Royal Society of Canada, is a James McGill Professor and the Imasco Chair of information systems in the Desautels Faculty of management at McGill University. He has held editorial positions in numerous journals, including being an associate editor at MISQ, associate and senior editor at ISR, and associate editor at Organization Science. His current research interests include the organizational and individual impacts of information technology, user adaptation, social networks, ERP implementation, e-health, e-integration, strategic alignment of IT, and the 
Reproduced with permission of the copyright owner. Further reproduction prohibited without permission. 